\title{
Rationale for the Choice of the Ellipsoidal Reflector Parameters for Biomedical Photometers
}

\author{
N. Bezuglaya, A. Haponiuk, D. Bondariev, S. Poluectov, V. Chornyi, M. Bezuglyi \\ National Technical University of Ukraine "Igor Sikorsky Kyiv Polytechnic Institute", \\ Peremohy Ave., 37, Kyiv 03056, Ukraine
}

Received 26.08.2021

Accepted for publication 09.11.2021

\begin{abstract}
Biomedical photometers' information-measuring systems with ellipsoidal reflectors have acceptable results in determining of biological tissues optical properties in the visible and near-infrared spectral range. These photometers make it possible to study the optical radiation propagation in turbid media for direct and inverse problems of light-scattering optics. The purpose of this work is to study the influence of the ellipsoidal reflectors design parameters on the results of biomedical photometry when simulating the optical radiation propagation in a system of biological tissue and reflectors in transmitted and reflected light.

The paper substantiates the choice of the ellipsoidal reflectors' focal parameter for efficient registration of forward and backscattered light. The methodology of the process is illustrated by the results of a model experiment using the Monte Carlo simulation for samples of human brain white and gray matter at the visible range of $405 \mathrm{~nm}, 532 \mathrm{~nm}$, and $650 \mathrm{~nm}$. The total transmittance, diffuse reflectance, and absorption graphs depending on the sample thickness were obtained. Based on the introduced concepts of the ellipsoidal reflector efficiency index and its efficiency factor, the expediency of choosing the ellipsoidal reflectors focal parameter is analyzed to ensure the registration of the maximum amount of scattered light. The graphs of efficiency index in reflected and transmitted light for different thickness samples of white and gray matter and efficiency factors depending on the sample thickness were obtained.

The influence of the reflectors ellipticity on the illuminance of various zones of photometric images using the example of an absorbing biological medium - pig liver tissue - at wavelength of $405 \mathrm{~nm}$ with a Monte Carlo simulation was analyzed.

The optical properties of biological media (scattering and absorption coefficients, scattering anisotropy factor, refractive index) and the samples' geometric dimensions, particularly the thickness, are predetermined when choosing the ellipsoidal reflectors parameters for registration of the scattered light. Coordinates of the output of photons and their statistical weight obtained in the Monte Carlo simulation of light propagation in biological tissue have a physical effect on a characteristic scattering spot formation in the receiving plane of a biomedical photometer with ellipsoidal reflectors.
\end{abstract}

Keywords: ellipsoidal reflector, biomedical photometer, biological tissue, optical properties.

DOI: $10.21122 / 2220-9506-2021-12-4-259-271$

\begin{tabular}{|c|c|}
\hline $\begin{array}{l}\text { Адрес для переписки: } \\
\text { Безугльй М.А. } \\
\text { Национальный технический университет Украиньл } \\
\text { «Киевский политехнический институт имени Игоря Сикорского», } \\
\text { пр-т Победыл, 37, г. Киев 03056, Украина } \\
\text { e-таil: m.bezuglyi@kрі.иа }\end{array}$ & $\begin{array}{l}\text { Address for correspondence: } \\
\text { Bezuglyi M.A. } \\
\text { National Technical University of Ukraine } \\
\text { "Igor Sikorsky Kyiv Polytechnic Institute", } \\
\text { PeremohyAve., 37, Kyiv 03056, Ukraine } \\
\text { e-mail: m.bezuglyi@kpi.ua }\end{array}$ \\
\hline $\begin{array}{l}\text { Для цитирования: } \\
\text { N. Bezuglaya, A. Haponiuk, D. Bondariev, S. Poluectov, } \\
\text { V. Chornyi, M. Bezuglyi. } \\
\text { Rationale for the Choice of the Ellipsoidal Reflector Parameters } \\
\text { for Biomedical Photometers. } \\
\text { Приборы и методы измерений. } \\
\text { 2021. - Т. 12, № 4. - C. 259-271. } \\
\text { DOI: } 10.21122 / 2220-9506-2021-12-4-259-271\end{array}$ & $\begin{array}{l}\text { For citation: } \\
\text { N. Bezuglaya, A. Haponiuk, D. Bondariev, S. Poluectov, } \\
\text { V. Chornyi, M. Bezuglyi. } \\
\text { Rationale for the Choice of the Ellipsoidal Reflector Parameters } \\
\text { for Biomedical Photometers. } \\
\text { Devices and Methods of Measurements. } \\
\text { 2021, vol. } 12 \text {, no. } 4 \text {, pp. } 259-271 \text {. } \\
\text { DOI: } 10.21122 / 2220-9506-2021-12-4-259-271\end{array}$ \\
\hline
\end{tabular}




\title{
Обоснование выбора параметров эллипсоидальных рефлекторов биомедицинских фотометров
}

\author{
Н.В. Безуглая, А.А. Гапонюк, Д.В. Бондарев, С.А. Полуэктов, В.А. Чёрный, \\ М.А. Безуглый
}

Нацииональный технический университет Украины

«Киевский политехнический институт имени Игоря Сикорского», пр-т Победыл, 37, г. Киев 03056, Украина

Поступила 26.08.2021

Принята к печати 09.11.2021

Информационно-измерительные системы биомедицинских фотометров с эллипсоидальными рефлекторами показали приемлемые результаты при определении оптических свойств биологических тканей в видимом и ближнем инфракрасном спектральном диапазоне. Такие фотометры позволяют исследовать распространение оптического излучения в мутных средах при прямой и инверсной задачах оптики светорассеяния. Целью данной работы являлось исследование влияния конструктивных параметров эллипсоидальных рефлекторов на результаты биомедицинской фотометрии при симуляции распространения оптического излучения в системе биологической ткани и рефлекторов.

В работе обоснован выбор фокального параметра эллипсоидальных рефлекторов для эффективной регистрации рассеянного вперёд и назад света. Методика процесса проиллюстрирована результатами модельного эксперимента при использовании метода Монте-Карло для образцов белого и серого вещества мозга человека на длинах волн видимого диапазона 405 нм, 532 нм и 650 нм. Получены графики зависимости полного пропускания, диффузного отражения и поглощения в зависимости от толщины исследуемого образца. На основе введённых понятий показателя эффективности и коэффициента эффективности проанализирована целесообразность выбора фокального параметра эллипсоидальных рефлекторов для обеспечения регистрации максимального количества рассеянного света. Получены графики показателей эффективности в отражённом и прошедшем свете для разнотолщинных образцов белого и серого веществ, а также коэффициентов эффективности в зависимости от толщины образца.

Проанализировано влияние эллиптичности рефлекторов на освещённость различных зон фотометрических изображений на примере поглощающей биологической среды - ткани печени свиньи на длине волны 405 нм при симуляции Монте-Карло.

Оптические свойства биологических сред (коэффициенты рассеяния и поглощения, коэффициент анизотропии рассеяния, показатель преломления) и геометрические размеры образцов, в частности толщина, предопределяют выбор параметров эллипсоидальных рефлекторов для регистрации рассеянного света. Координаты выхода фотонов и их статистический вес, полученные при моделировании распространения света в биологической ткани методом Монте-Карло, оказывают физическое влияние на формирование характерного пятна рассеяния в приёмной плоскости биомедицинского фотометра.

Ключевые слова: эллипсоидальный рефлектор, биомедицинский фотометр, биологическая ткань, оптические свойства.

DOI: $10.21122 / 2220-9506-2021-12-4-259-271$

\begin{tabular}{|c|c|}
\hline Адрес для переписки: & Address for correspondence: \\
\hline Безугльій М.A. & Bezuglyi M.A. \\
\hline Национальнылй технический университет Украиньл & National Technical University of Ukraine \\
\hline «Киевский политехнический институт имени Игоря Сикорского», & "Igor Sikorsky Kyiv Polytechnic Institute”, \\
\hline пр-т Победыл, 37, г. Киев 03056, Украина & Peremohy Ave., 37, Kyiv 03056, Ukraine \\
\hline e-mail:m.bezuglyi@kpi.ua & e-mail:m.bezuglyi@kpi.ua \\
\hline Для цитирования: & For citation: \\
\hline N. Bezuglaya, A. Haponiuk, D. Bondariev, S. Poluectov, & N. Bezuglaya, A. Haponiuk, D. Bondariev, S. Poluectov, \\
\hline V. Chornyi, M. Bezuglyi. & V. Chornyi, M. Bezuglyi. \\
\hline Rationale for the Choice of the Ellipsoidal Reflector Parameters & Rationale for the Choice of the Ellipsoidal Reflector Parameters \\
\hline for Biomedical Photometers. & for Biomedical Photometers. \\
\hline Приборы и методы измерений. & Devices and Methods of Measurements. \\
\hline 2021. - T. 12, № 4. - С. 259-271. & 2021, vol. 12 , no. 4 , pp. $259-271$. \\
\hline DOI: $10.21122 / 2220-9506-2021-12-4-259-271$ & DOI: $10.21122 / 2220-9506-2021-12-4-259-271$ \\
\hline
\end{tabular}




\section{Introduction}

Biomedical photometers (separate devices) and photometric systems (composite modules of diagnostic complexes) use the entire range of optical systems, the converting properties of which have been adequately described and studied. Moreover, regardless of the photometer type, the energetic or visualizing features of optical systems are the basis for researching with the required accuracy.

In recent years, tools for optical diagnostics of scattering objects have become widespread. This class of devices is in demand for the study of surfaces and the optical properties of scattering (turbid) media, biological tissues, and liquids. As a rule, the typology of the measurements carried out makes it possible to distinguish reflective photometry, transmittance photometry, and photometry for both reflection and transmission [1,2]. Obviously, the main determining factor is the predicted ability of the research object to the optical radiation penetration (forward scatter) or reflection (backward scatter). It should be noted that depending on the incident light parameters (for this class of devices, as a rule, laser), the received luminous flux contains components that characterize the surface topography, a boundary separating two media, and scattering properties in a quasi-homogeneous layer. Such features and requirements for the information content of photometry predetermine the need to increase the amount of registered light, which is achieved by selecting contactless measurement methods and optical systems with a wide aperture, or by using contact measurements with optical elements of the atypical configuration. Such optical elements are ellipsoidal reflectors (ER), which are widely used for a rough surface control [1]. Biomedical use of ellipsoidal reflectors [2] in the framework of numerical modeling by the inverse Monte Carlo allows obtaining acceptable results in determining the optical properties of biological tissues (BT) [3]. On the other hand, the direct Monte Carlo method [2,6] is one of the few methods that allows graphical interpretation of the scattered light characteristics in the forward and backward direction. In this case, the parameters of an actual light source are taken into account by adjusting the number of photons involved in the simulation, furthermore by predetermining the diameter and profile of the laser radiation, which is sufficiently well approximated in the same way, as, for example, in $[7,8]$. The correct choice of the ellipsoidal reflectors design parameters is associated with the specific gravity of optical radiation, which is subsequently capable of registering a photodetector and is one of the significant factors affecting the accuracy of determining the scattering $\mu_{s}$ and absorption $\mu_{a}$ coefficients, as well as the scattering anisotropy factor $g$ by inverse methods of the radiative transfer theory.

The purpose of this work is to study the influence of the ellipsoidal reflectors design parameters on the results of biomedical photometry when simulating the optical radiation propagation in a system of biological tissue and reflectors in transmitted and reflected light.

\section{The ellipsoidal reflectors configuration of biomedical photometers}

This paper analyzes the design parameters of a mirror ellipsoid of revolution, orthogonally truncated along the focal planes (Figure 1a). This type of reflector was used to determine the biological media optical properties in reflected, as well as in reflected and transmitted light $[4,5]$. In this case, the ellipsoid, intended for the formation of the optical radiation incident on the object, contains an opening of diameter $D$, centered on the semi-minor axis, for introducing radiation into the reflector cavity (Figure $1 b$ ).

In general, the shape of an ellipsoid of revolution is given by the canonical equation:

$\frac{x^{2}}{c^{2}}+\frac{y^{2}}{b^{2}}+\frac{z^{2}}{a^{2}}=1$,

where $c, b$ are semi-minor axes; $a$ is semi-major axis of an ellipsoid of a given configuration.

Given the optical radiation formation and registration systems axial symmetry, it is advisable to produce an ellipsoidal reflector symmetric concerning the $z$-axis. Then in equation (1) $c=b$. The main design parameters that affect the operation of photometric biomedical systems using an ellipsoidal reflector include its eccentricity $e$, which is calculated according to formula (2), and the focal parameter $p$, obtained from formula (3):

$$
\begin{aligned}
& e=\sqrt{1-\frac{b^{2}}{a^{2}}}, \\
& p=\frac{b^{2}}{a}=a\left(1-e^{2}\right)=b \sqrt{1-b^{2}} .
\end{aligned}
$$




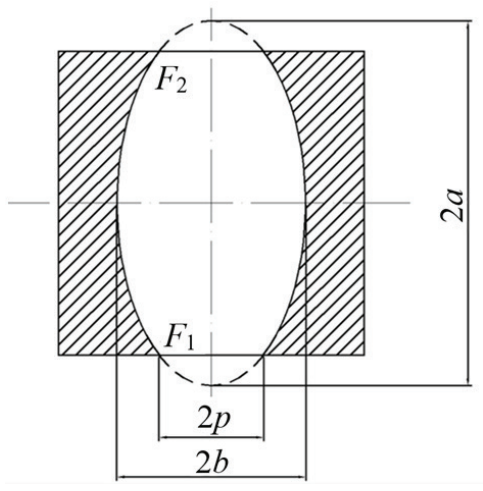

$a$

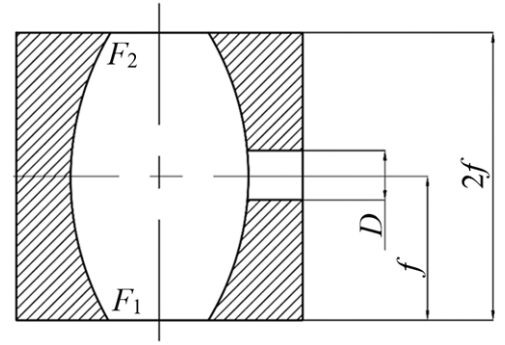

$b$

Figure 1 - Design parameters of an ellipsoidal reflector for registering transmitted $(a)$ and reflected $(b)$ light: $F_{1}$, $F_{2}$ - focus points; $f$ - focal distance

The eccentricity quantity affects the ellipsoid elongation, with an aspect ratio (ellipticity) that can be determined as:

$$
m=\frac{b}{a} \text {. }
$$

Obviously, the larger the ellipticity, the less elongated the ellipsoid will be. This aspect is essential since, mathematically, an ellipsoid can be obtained from a sphere by uniformly compressing it in two coordinates, with the third unchanged (for example, $z$ ). The technical implementation of this method was applied in the development of technology for obtaining deep non-spherical surface by trajectory copying method [9] of the output circle to obtain ellipsoidal reflectors prototypes. In general, coordinating the movement along the longitudinal axis with plunging into the workpiece material, an ellipsoid is obtained with the required shape of the generatrix, changing according to the required formula (1).

As a material for an ellipsoidal reflector, it is advisable to use metal or glass; the turning and abrasive processing technology is quite simple and inexpensive. The ultimate goal of such processing is to obtain an internal curved surface with high reflectivity in a wide range of wavelengths. From the research object point of view - the biological tissue - the therapeutic window [10] determines the spectral range of the entire photometric system and, accordingly, sets a requirement for the stability of the reflector reflectance. Therefore, reflector produces can use a substrate (glass, plastic, polymers, or, in some ones, metal) with the working surface required shape of an ellipsoid of revolution and a reflective coating applied to it [1114]. This method is advisable to use for radiation with a complex spectral composition [15]. Applying a coating, are achieve reflectance in a wide range of wavelengths, or, conversely, partial reflectance at specific wavelengths [16]. In addition, the application of a coating on involved or partially closed surfaces causes specific technological difficulties. Another method is to make an ellipsoid from a material that already has the reflecting property in a given spectral range [17]. This, in turn, significantly reduces the required equipment list and reduces the final product cost.

Considering the photometric system's application field with ellipsoids of revolution with an internal reflecting surface, the possibility of contact with biological tissue under in vivo experiment, the requirements of bio-inertness, it is recommended to make a reflector from a material with reflectance properties. Numerous data [17] confirm that the optimal for this aim is polished aluminum (aluminum alloys) with the most uniform reflection coefficient distribution within the therapeutic window. Low weight is another advantage of using aluminum. On the other hand, the relatively large coefficient of linear thermal expansion imposes special conditions and limits the photometric core use at fluctuating temperatures. Experience has shown that the best abrasive processing purity is achieved when using finely dispersed homogeneous alloys. Therefore, at produced the ellipsoidal reflector for the information-measuring system prototype, the material D16T was used (analog of ENAW-2024).

Thus, two critical ellipsoidal reflector parameters can be distinguished: the ellipticity $m$ and the focal parameter $p$, which specify the photometric core configuration with an internal reflecting surface and a specular reflection coefficient. 


\section{Influence of the focal parameter on the ellipsoidal reflector efficiency}

Consider the rationale for choosing the ellipsoidal reflector focal parameter $(p)$ for photometry of biological tissues light scattering. This value is the working window size of the photometric system in contact with biological tissue. The working window's main aim is to collect the maximum and, if possible, all the optical radiation that came out of the biological tissue in forward or backscattered light within the solid angle of $2 \pi$.

When researching in vitro, the biological tissue samples size determines the focal parameter value. Since the interaction area of optical radiation with a tissue sample is physically limited by its size, it is sufficient to ensure that the focal parameter exceeds the largest size of the biological tissue sample to collect all scattered radiation. The sample is often placed between two glass plates, which, due to light refraction, deviate the rays scattered in the tissue by a particular value depending on the plate's thickness and the refractive index, which must also be taken into account when choosing the parameter $p$. In clinical practice, measuring instruments of various "calibers" are often used for various geometrical dimensions objects; this is done, for example, when choosing a sensor for an electromagnetic blood flow meter [18]. Therefore, in vivo studies, it is advisable to either use a universal photometric core with the working window size which is guaranteed to ensure the registration of all scattered light, regardless of the absorption and scattering characteristics in a multilayer biological media, or to have a set of ellipsoidal reflectors with the same ellipticity $\mathrm{m}$ and specular reflection coefficient, but with different focal parameters.

Since the amount of light scattered by biological tissue directly depends on the incident flux value, then by varying the light source power and the illumination area, it is also possible to choose the optimal focal parameter. However, this, in turn, requires restructuring and calibration of the measuring system photometric core, which is unacceptable under the normal experiment conditions.

The sample geometric dimensions correct definition will take into account the features of in vitro experiment [3] using ellipsoidal reflectors and determine the ellipsoid focal parameter for in vivo measurements correctly. In this case, the valuable component of the scattered light signal will be within the measuring apertures. That it is necessary to predict the maximum possible size of the scattering spot on the biological tissue surface. With high accuracy, this is possible at the Monte Carlo simulation of laser radiation propagation in optically turbid media [19]. The estimate can be made taking into account the extremal coordinates of the photon exit from the BT. The optimized algorithm makes it possible to estimate the coordinates of the exit points from the medium of each photon participating in the simulation in the forward and backward directions for an infinitely thin laser beam or a finite diameter beam with a uniform or Gaussian transverse profile.

Having characterized the results of the interaction of the optical radiation with biological media at the Monte Carlo simulation can single out the following significant parameters that will affect the scattering spot size in the forward and backward directions. First of all, these are the photon exit coordinates from the BT; secondly, the direction cosines, which characterize the ray (photon) propagation direction and the point of its intersection with the ellipsoidal surface of the biomedical photometer reflector; and thirdly, this is the photon weight at the exit from the BT, which characterizes the illuminance in the contact plane of the BT and the ER focal plane. It is possible to analyze the indicated parameters and evaluate their influence on the ER focal parameter and ellipticity by modeling for BT with different, conditionally boundary optical properties.

Consider the features of light scattering in biological tissues during photometry by ellipsoidal reflectors using the example of single-layer model structures of human brain tissues that simulate an experiment in vitro for three wavelengths of the visible range: $405 \mathrm{~nm}, 532 \mathrm{~nm}$, and $650 \mathrm{~nm}$ (Table 1). The refractive index for brain tissue is for white matter 1.467 , and for gray matter is 1.395 [20].

Due to a relative deviation of their scattering and absorbing properties, the biological tissues' choice for a model experiment does not limit the information-measuring system capabilities of a biomedical photometer. However, it only outlines the practical selection principles of ER design parameters.

The determine the optimal focal parameter of the ellipsoidal reflector to a specific object of biological research should be carried out taking into account ER efficiency index, that is, the weight of photons leaving the BT in the forward or backward direction with coordinates, located in a circle of radius $p$. At the Monte Carlo simulation, it is assumed that a packet of photons follows each pathway and some portion of the packet is absorbed during 
interaction (absorption or scattering). The size of such a packet is called the weight of a photon with an initial value of one. In the model experiment, the coefficients that determine the BT optical properties at the Monte Carlo simulation are total transmittance $T$, absorption $A$, diffuse reflectance $R_{d}$ and specular $R_{s}$ reflectance; therefore, the ER efficiency index in the forward and backscattered light, respectively, are determined as follows:

$$
K_{T}=\frac{W_{T}}{T \cdot N_{0}}
$$

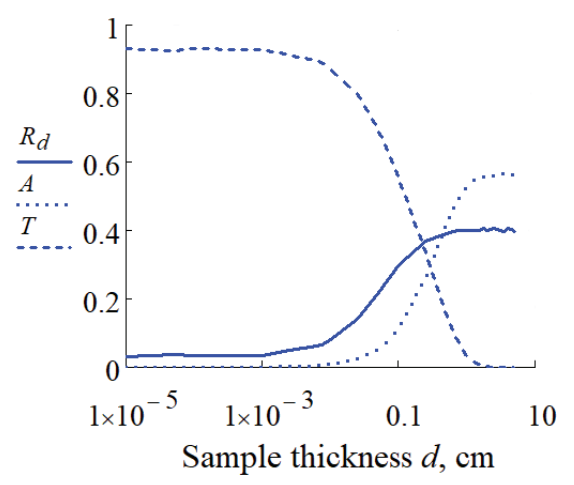

$a$
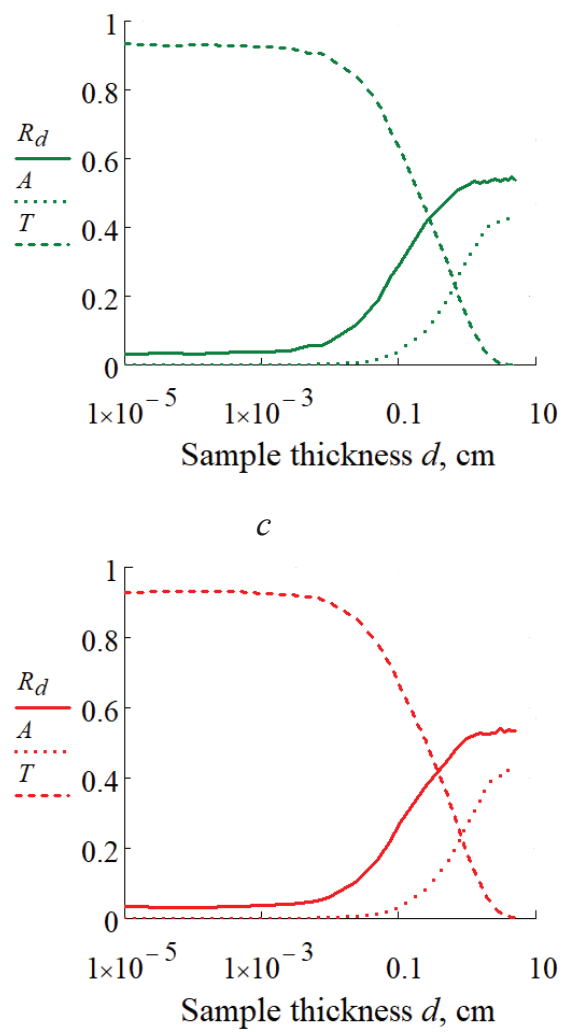

$e$

$$
K_{R}=\frac{W_{R}}{\left(R_{d}+R_{S}\right) \cdot N_{0}},
$$

where $N_{0}$ is the total number of photons launched in tissue; $W_{T}, W_{R}$ is the total weight of photons leaving the tissue in the forward and backscattered light, respectively, with coordinates located within the ER working window with a diameter of $2 p$.

Figure 2 shows the total transmittance, absorption, and diffuse reflectance depending on the thickness of the simulated mono-layers obtained during the Monte Carlo simulation [22, 23] of light propagation in the biological tissue under study.

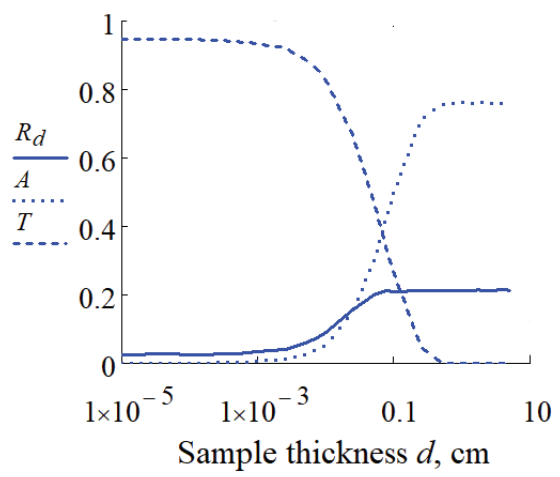

$b$

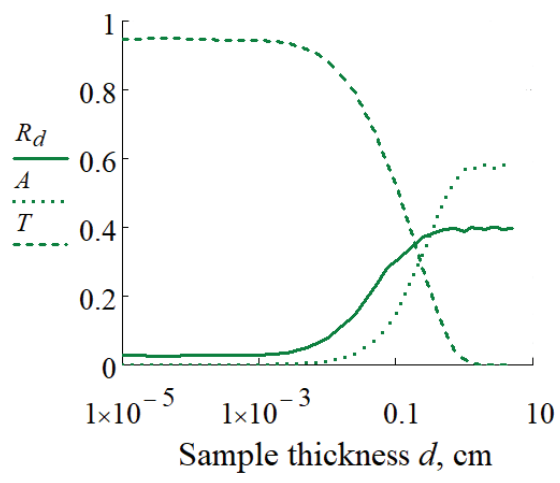

$d$

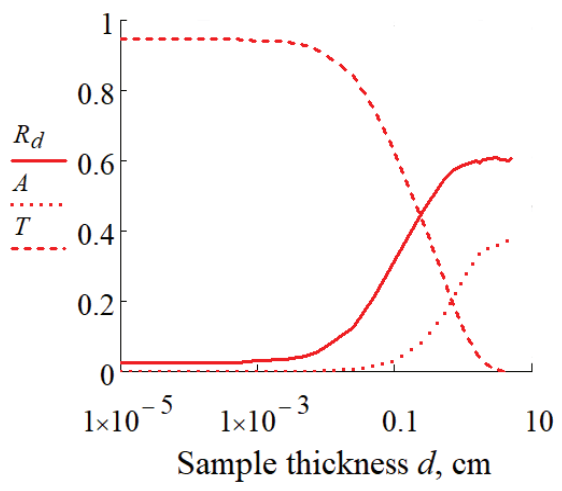

$f$

Figure 2 - Dependence of diffuse reflectance $R_{d}$ (solid line), absorption $A$ (dotted line), total transmittance $T$ (dashed line) on the sample thickness $d$ for human brain tissues: white matter $(a, c, e)$; gray matter $(b, d, f)$; for wavelengths $405 \mathrm{~nm}(a, b), 532 \mathrm{~nm}(c, d)$ and $650 \mathrm{~nm}(e, f)$, respectively 
Optical properties of biological tissues [21]

Table 1

\begin{tabular}{lccccccccccc}
\hline Wavelength, nm & \multicolumn{3}{c}{$405 \mathrm{~nm}$} & \multicolumn{3}{c}{$532 \mathrm{~nm}$} & \multicolumn{3}{c}{$650 \mathrm{~nm}$} \\
\hline Optical properties & $\begin{array}{c}\mu_{a}, \\
\mathrm{~cm}^{-1}\end{array}$ & $\begin{array}{c}\mu_{s}, \\
\mathrm{~cm}^{-1}\end{array}$ & $g$ & $\begin{array}{c}\mu_{a}, \\
\mathrm{~cm}^{-1}\end{array}$ & $\begin{array}{c}\mu_{s}, \\
\mathrm{~cm}^{-1}\end{array}$ & $g$ & $\begin{array}{c}\mu_{a}, \\
\mathrm{~cm}^{-1}\end{array}$ & $\begin{array}{c}\mu_{s}, \\
\mathrm{~cm}^{-1}\end{array}$ & $g$ \\
\hline Human white matter & 0.31 & 40.2 & 0.76 & 0.1 & 41 & 0.815 & 0.08 & 40.1 & 0.852 \\
Human gray matter & 2.33 & 126.7 & 0.862 & 0.45 & 102.2 & 0.89 & 0.09 & 86.2 & 0.898 \\
\hline
\end{tabular}

Comparing the results obtained with similar distributions $[23,25]$ for photometric images in biometry of media by ellipsoidal reflectors method, single out the characteristic range of sample thickness with the highest brightness on the image field is observed. As shown in papers $[23,25]$ the "brightest" photometric images are formed on the thicknesses of biological tissue samples with the most dynamical deviation of optical coefficients $R_{d}, A$, and $T$. In this regard, as well as the need for a relative comparison of the ER efficiency when working with samples of different BT, the following thicknesses for the studied brain tissues $d_{1}=0.025 \mathrm{~cm}, d_{2}=0.05 \mathrm{~cm}, d_{3}=0.1 \mathrm{~cm}, d_{4}=0.5 \mathrm{~cm}$, $d_{5}=2.5 \mathrm{~cm}$ were used for modeling. This range of thicknesses is an estimate solely from the prognostic positions of photometry by ellipsoidal reflectors: it does not characterize the generally accepted principles of biopsy research, the study of lyophilized or paraffinized slices and is not anatomically verified.

Consider graphs of the ER efficiency indexes dependence in the forward $K_{T}$ (Figure 3) and backscattered $K_{R}$ (Figure 4) light for the white and grey matter samples of the human brain at the different wavelengths. To simulate the light propagation in the system of biological tissue and a photometer with ellipsoidal reflectors, in addition to the BT optical properties of the indicated spectra (Table 1), the following initial data were used: the number of launched photons - 20 million, the incident laser beam profile [26] is Gaussian, the laser beam diameter $2 r_{0}=1.5 \mathrm{~mm}$. The ER efficiency indexes are given depending on the quantity ratio that characterizes the discrete values $r_{i}$ of the $i$-th photons output coordinates to the incident beam radius $r_{0}$.

As shown in Figures 3 and 4 for the studied human brain tissues, there is a tendency to increase the focal parameter $p$ with an increase in the BT samples thickness, which ensures the achievement of the maximum values of the ER efficiency index reflected $K_{R}$ and transmitted $K_{T}$ light. In Figure $3 b$, there is no graph for a sample of the brain gray matter with a $2.5 \mathrm{~cm}$ thickness at a wavelength of $405 \mathrm{~nm}$, which is due to the zero value of the transmittance $T$ (Figure $2 d$ ) for a given sample thickness. For the studied human brain tissues with a thickness of $2.5 \mathrm{~cm}$ in the visible spectrum for both transmitted and reflected light (Figures 3 and 4), the ER efficiency indexes converge to one at values of the focal parameter, which exceeds the incident beam diameter at least at five times. Therefore, the samples thickness, which significantly affects the scattering spot size in reflected and/or transmitted light, is also one of the defining parameters that will affect the efficiency of the corresponding ellipsoidal reflector. Considering the graphs' nature, those shown in Figures 3 and 4, will estimate the ER efficiency dependence on the BT sample thickness. The ER efficiency factor means the ER efficiency index approximation to the unity with given accuracy and is defined as:

$$
\begin{gathered}
Q_{T}=\left.\frac{r_{0}}{r_{i}}\right|_{K_{T} \rightarrow 1} ; \\
Q_{R}=\left.\frac{r_{0}}{r_{i}}\right|_{K_{R} \rightarrow 1} .
\end{gathered}
$$

Figure 5 shows the dependence of the ER efficiency factor in reflected $Q_{R}$ and transmitted $Q_{T}$ light for different thickness samples of the white and gray matter of a human brain for the studied spectrum lines. To create the graphs in Figure 5 , we used the coefficients approximation with $0.001(0.1 \%)$ error.

The graphs of $Q_{R}$ with increasing thickness will not experience further changes since the diffuse reflection coefficient, reaching a specific value, remains constant (Figure 2) with any further increase of the BT sample thickness $d$ in all studied wavelengths. In this case, the factor $Q_{T}$ will begin to overgrow upon reaching a certain critical thickness (for example, a graph at a wavelength of $405 \mathrm{~nm}$ in Figure $5 b$ for the human brain gray matter) when the total transmittance $T$ 
approached zero. Since there will be no transmittance, the photons radius $r_{i}$ that leaves the BT sample in the forward direction will not be a physically significant quantity. This will indicate the onset of mathematical uncertainty, in which the denominator (7) will have

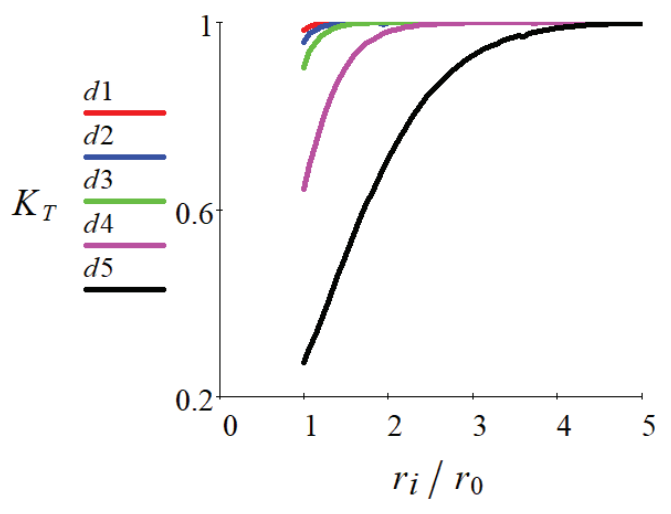

$a$

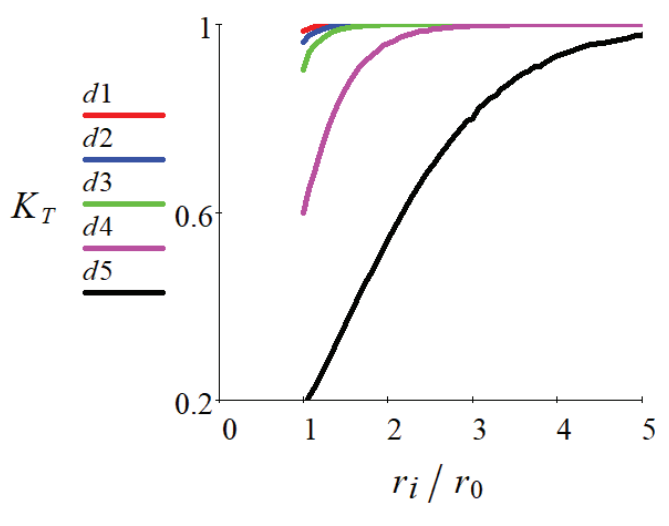

$c$

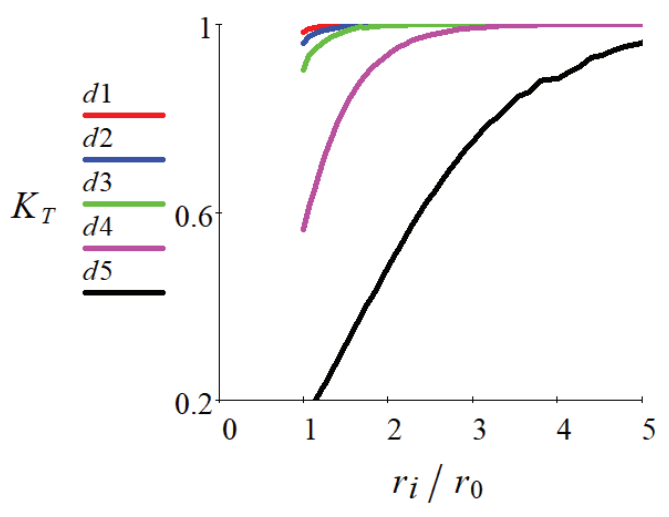

$e$ a zero (none-xistent) value. There will be no reason to use ER to transmittance measure, and the bottom reflector will make the monitoring function of the correct operation of a light propagation simulation model in the biomedical photometer system.

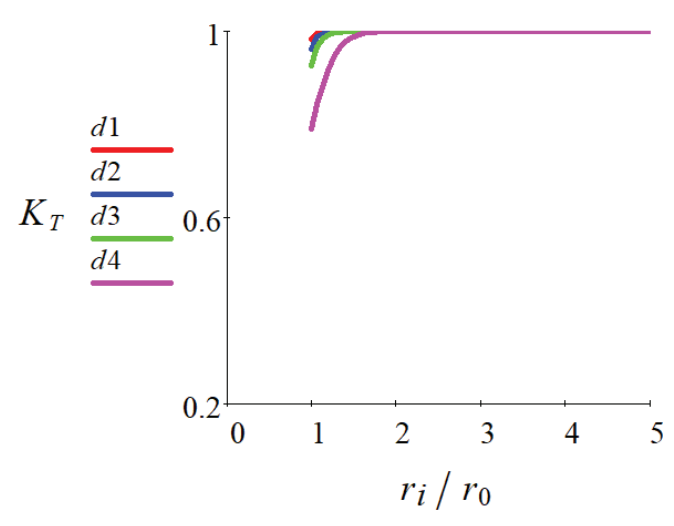

$b$
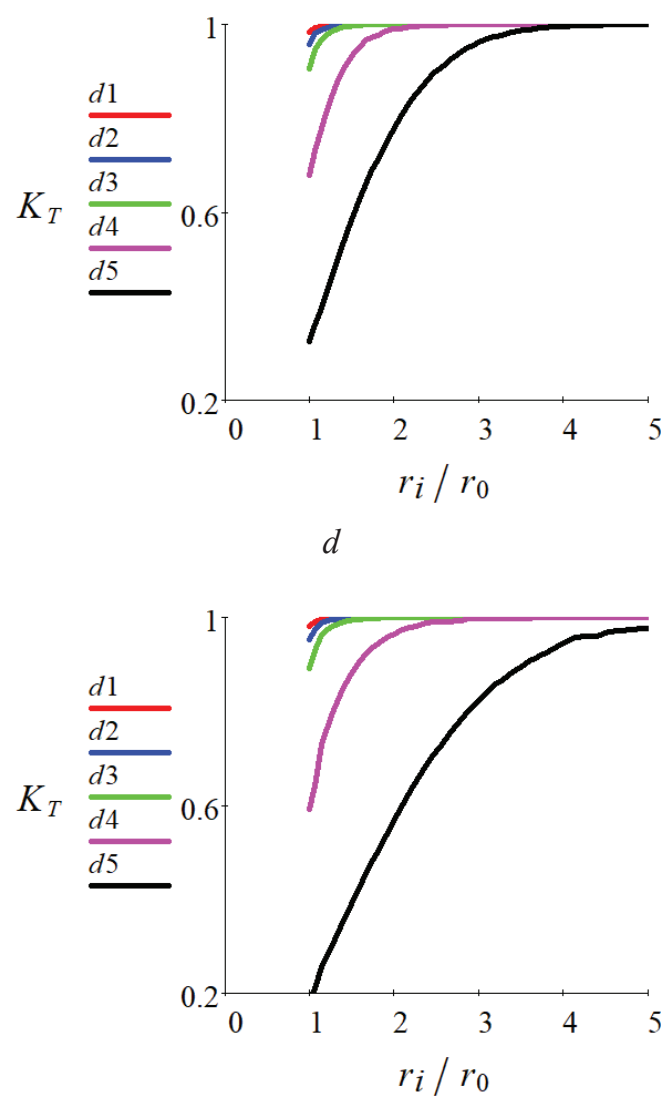

$f$

Figure 3 - Dependence of ellipsoidal reflectors efficiency index in transmitted light on ratio $r_{i} / r_{0}$ for human brain tissues: white matter $(a, c, e)$ and gray matter $(b, d, f)$ for wavelengths $405 \mathrm{~nm}(a, b), 532 \mathrm{~nm}(c, d), 650 \mathrm{~nm}(e, f)$, respectively

For the human brain white and gray matter at selected wavelengths, the ER efficiency index for collecting diffuse reflection (backscattered light) approaches 1 when the focal parameter of the reflector exceeds the incident beam diameter by at least three times. At the same, for the transmitted (scattered forward) light, such excess should be more than six times. 

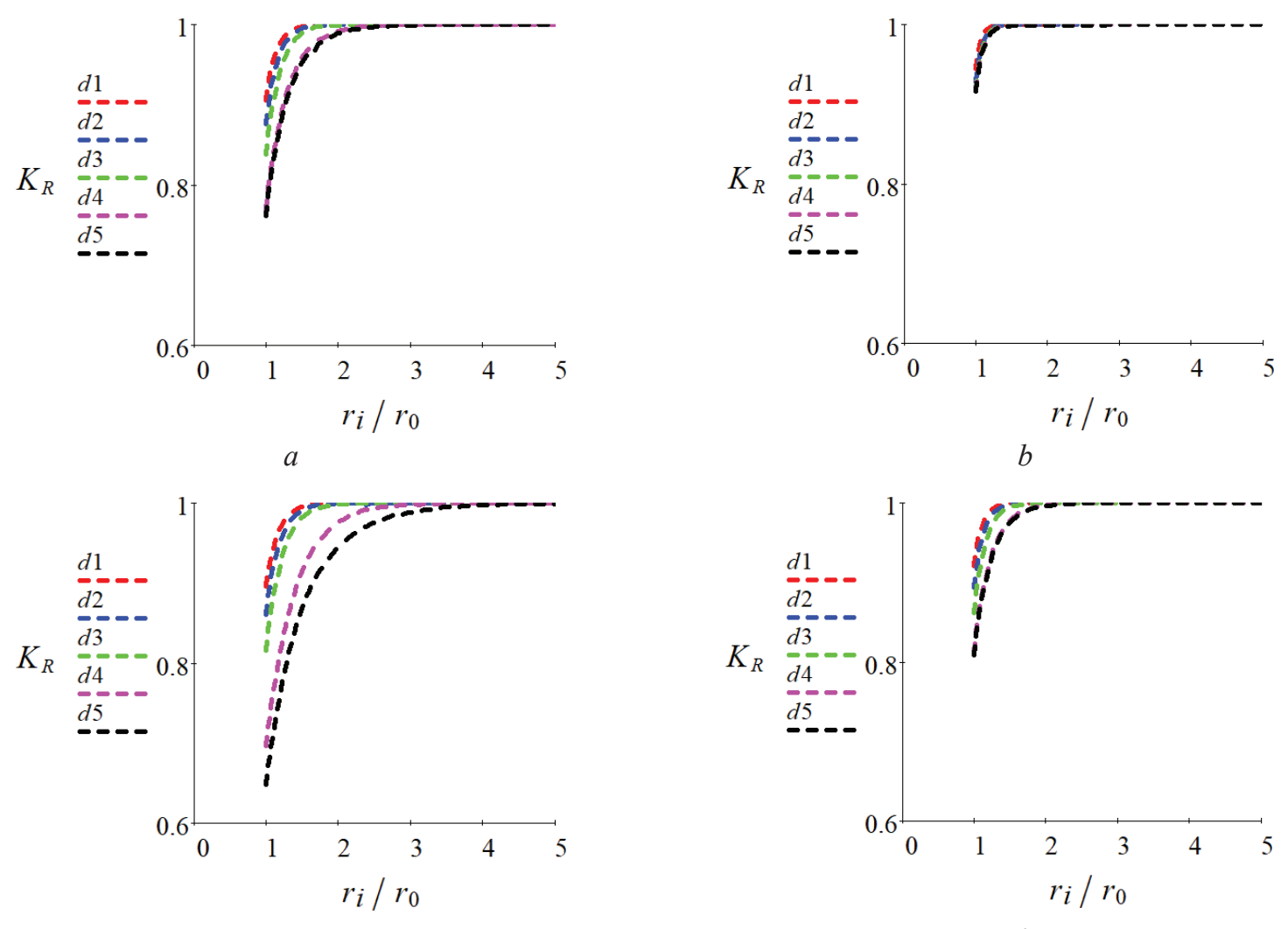

c
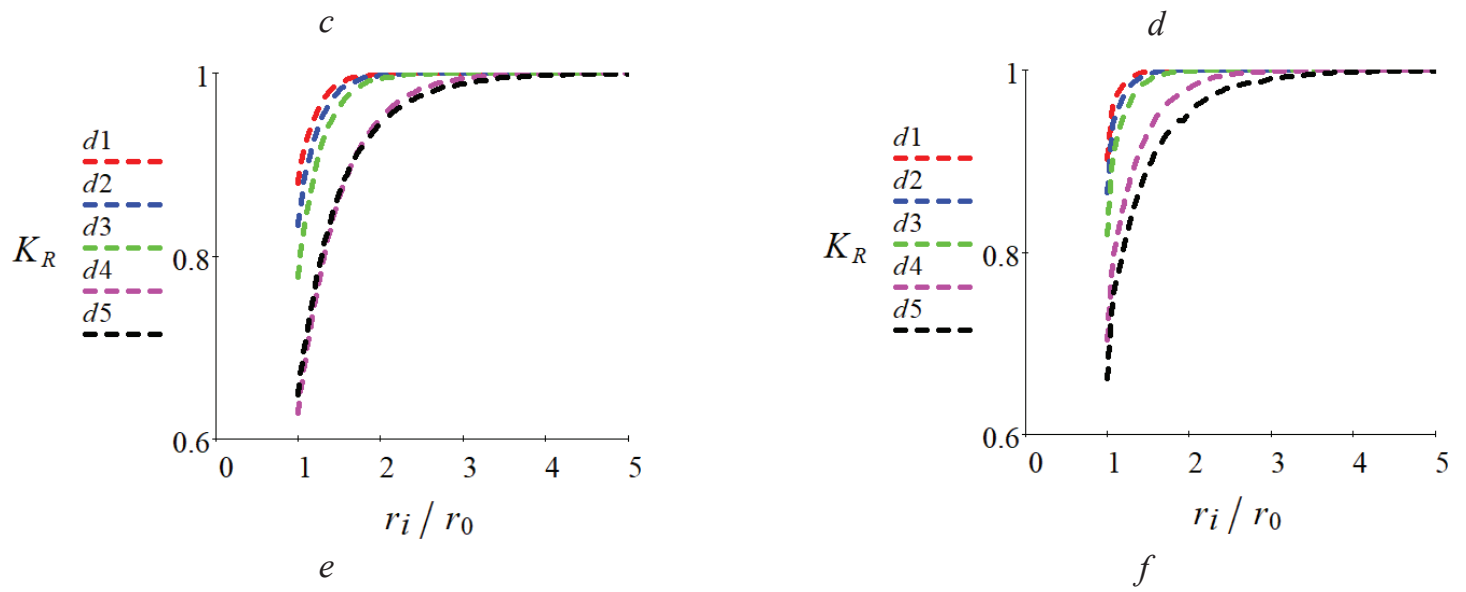

Figure 4 - Dependence of ellipsoidal reflectors efficiency index in reflected light on ratio $r_{i} / r_{0}$ for human brain tissues: white matter $(a, c, e)$ and gray matter $(b, d, f)$ for wavelengths $405 \mathrm{~nm}(a, b), 532 \mathrm{~nm}(c, d), 650 \mathrm{~nm}(e, f)$, respectively

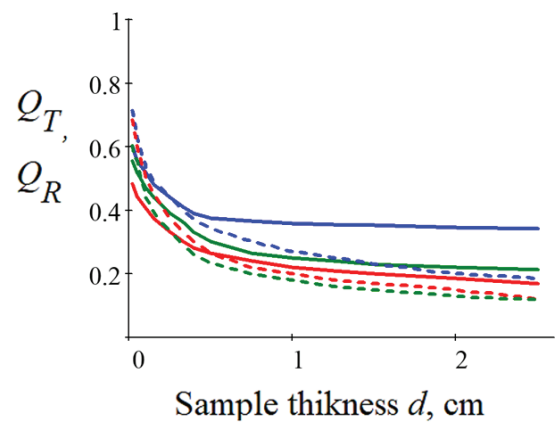

$a$

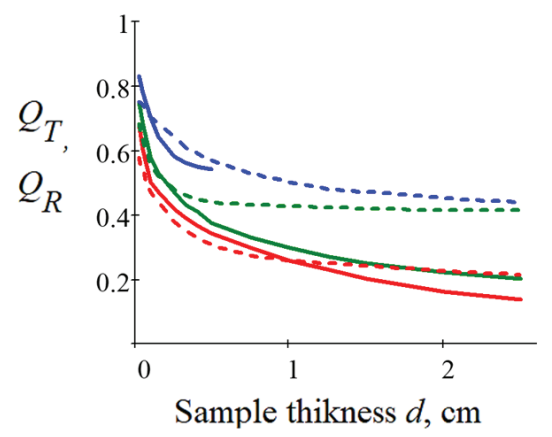

$b$

Figure 5 - Dependence of ellipsoidal reflectors efficiency factor on the sample thickness $d$ for human brain tissues: white matter $(a)$ and gray matter $(b)$ for wavelengths $405 \mathrm{~nm}$ (blue line), $532 \mathrm{~nm}$ (green line), $650 \mathrm{~nm}$ (red line) in reflected (dotted line) and transmitted (solid lane) light respectively 
Thus, choosing ellipsoidal reflectors with the same design parameters for registering the transmitted and reflected light ensures the optimum ER efficiency factor unify the computational algorithm and the BT optical properties determining process based on the maximum optical signal. The ER focal parameter $p$ exceeds the laser beam diameter used in experimental photometry with ellipsoidal reflectors [3-5, $23,25]$ by more than ten times. Therefore, their practical application in optical biometry of human brain tissues in the visible range is possible and expedient.

\section{Ellipsoidal reflector ellipticity substantiation}

When assessing the effect of the ER ellipticity, it should be noted that the focal parameter $p$ has already been determined and guaranteed to ensure the capture of scattered photons in the forward and backward directions with optimal efficiency factors (7) and (8), respectively. Taking into account the zone illuminance of photometric images of potentially scattering and quasi-scattering media $[23,25$, 26], which include the human brain tissue, for the ellipticity influence, it is reasonable to consider biological tissue with a priori absorbing properties at the selected wavelength. Photometric images formation and the different zone illuminance levels from the ER ellipticity influence at a wavelength of $405 \mathrm{~nm}$ for a pig liver tissue sample, the optical properties of which are given in Table 2, will be evaluated.

Table 2

\section{Optical properties of pig liver tissue [27]}

\begin{tabular}{lccccc}
\hline $\begin{array}{l}\text { Wave- } \\
\text { length, } \mathrm{nm}\end{array}$ & $\begin{array}{c}\mu_{a}, \\
\mathrm{~cm}^{-1}\end{array}$ & $\begin{array}{c}\mu_{s}, \\
\mathrm{~cm}^{-1}\end{array}$ & $g$ & $n$ & $d, \mathrm{~cm}$ \\
\hline 405 & 0.66 & 1.22 & 0.76 & 1.39 & 0.1 \\
\hline
\end{tabular}

Referring to the illuminance dependence on the sample thickness for the different zones of photometric images [23, 25, 26], let us fix its value at $1 \mathrm{~mm}$. The simulation was carried out by launching 20 million photons with a uniform profile of the incident laser beam [26] with a radius of $0.75 \mathrm{~mm}$ for the range of ER ellipticity values from 0.3 to 0.95 and focal parameters of $11 \mathrm{~mm}, 16.875 \mathrm{~mm}$, and $22.75 \mathrm{~mm}$. The lower limit of the specified range characterizes the $5 \%$ deviation of the ellipsoidal reflector shape from the spherical one, i. e., characterizes the physical feasibility of the ER functioning from the standpoint of optics. The upper limit, in turn, determines the limit of ellipticity in the produce of reflectors by the considered methods, i. e., technological feasibility.

As a result of the simulation, a series of photometric images were obtained; the typical appearance for forward and backscattered light is shown in Figure 6 .

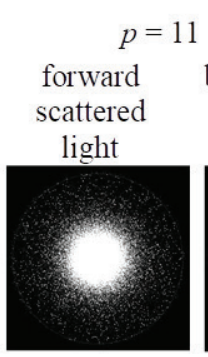

$a$

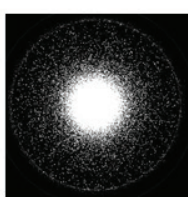

$g$

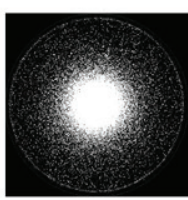

m

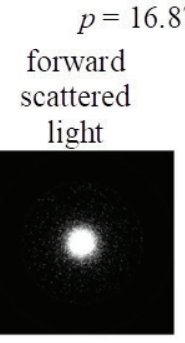

c

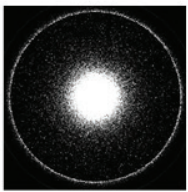

$h$

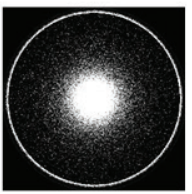

$n$

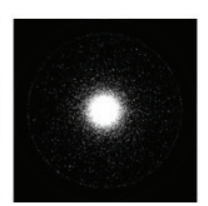

$i$

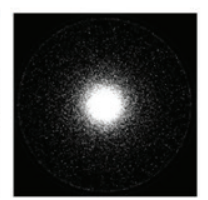

$O$
$75 \mathrm{~mm}$

ackscattered

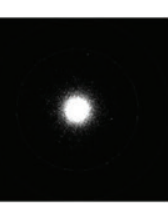

$d$

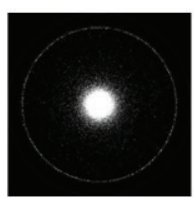

j

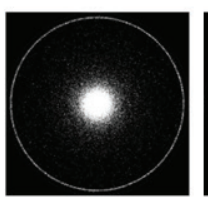

$p$

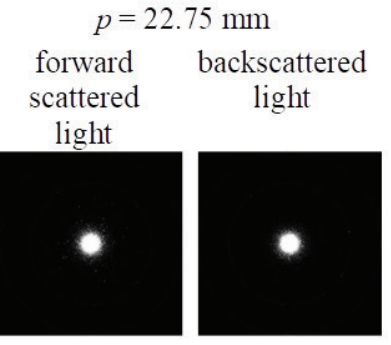

e

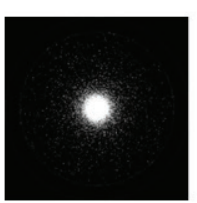

$k$

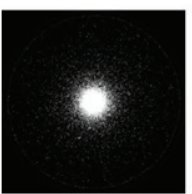

$q$

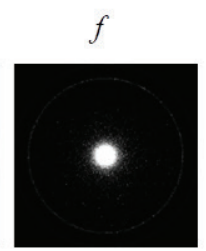

1

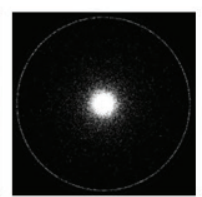

$r$

Figure 6 - Photometric images of forward $(a, c, e, g, i, k, m, o, q)$ and backward $(b, d, f, h, j, l, n, p, r)$ scattered light for the wavelength of $405 \mathrm{~nm}$ for pig liver tissue $1 \mathrm{~mm}$ thick at photometry by ellipsoidal reflectors with different focal parameters and ellipticity of $0.93675(a, b, g, h, m, n), 0.8352(c, d, i, j, o, p)$ and $0.6614(e, f, k, l, q, r)$ respectively 
Photometric images analyzing (Figure 6) shows a significant dependence of both the total field illuminance and its zones on the ER ellipticity at different values of the focal parameter. This fact confirms the geometric meaning of the influence of the reflector design parameters on its functional features. It makes it possible to foresee their (parameters) optimization for the study of a specific biological media.

Based on the zone analysis principles in processing of photometric image at photometry by ellipsoidal reflectors [25], the graphs of the illuminance

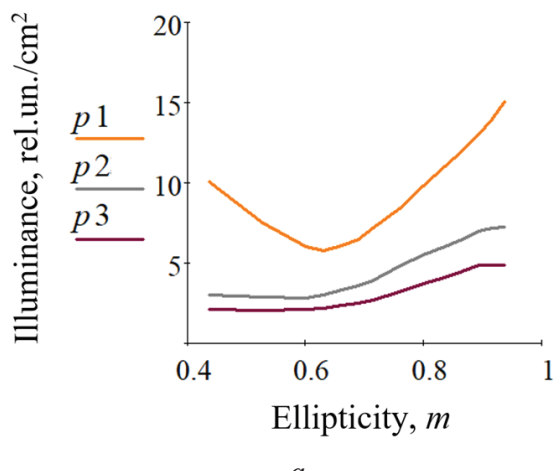

of external and middle rings from the ER ellipticity for forward (Figure 7) and backscattered (Figure 8) light were obtained.

The graphs in Figures 7 and 8 have the same dependence of the illuminance of the external and middle rings of photometric images on the ER ellipticity and come to approximately the value of 0.6 , and then grow rather quickly. In this case, there are more large values of the illuminance level for the ER with a smaller focal parameter value for the entire range of ellipticity.

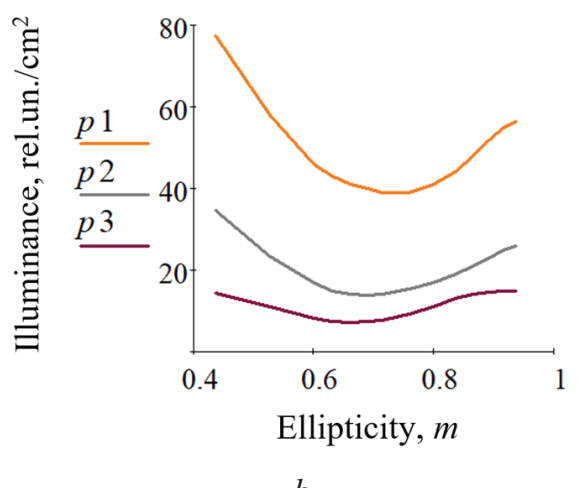

$b$

Figure 7 - Dependence of illuminance of external $(a)$ and middle $(b)$ rings of photometric images in forward scattered light on the ellipsoidal reflector ellipticity for a wavelength of $405 \mathrm{~nm}$ for $1 \mathrm{~mm}$ pig liver tissue samples at the values of the ellipsoidal reflector focal parameter $p_{1}=11 \mathrm{~mm}, p_{2}=16.875 \mathrm{~mm}$ and $p_{3}=22.75 \mathrm{~mm}$

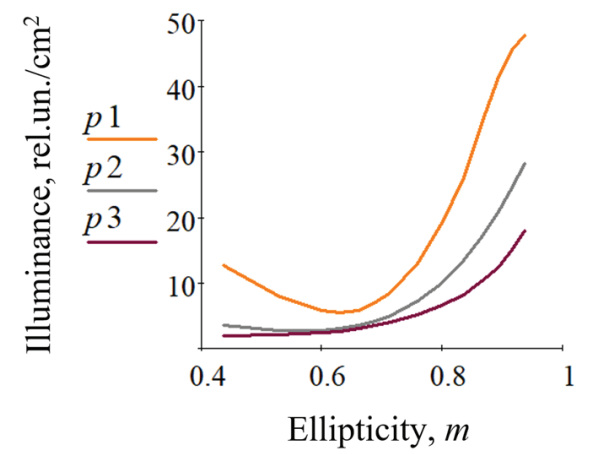

$a$

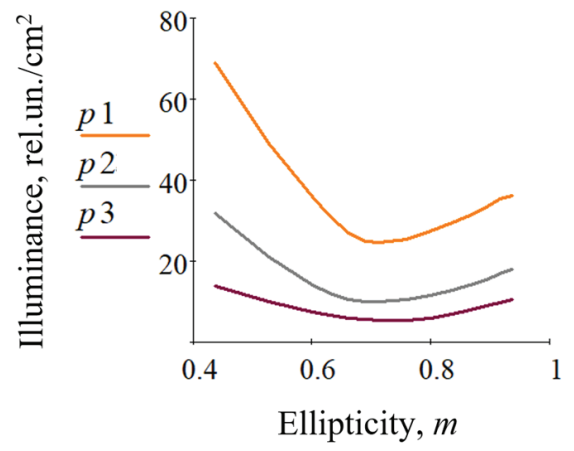

b

Figure 8 - Dependence of illuminance of external $(a)$ and middle $(b)$ rings of photometric images in backscattered light on the ellipsoidal reflector ellipticity for a wavelength of $405 \mathrm{~nm}$ for $1 \mathrm{~mm}$ pig liver tissue samples at the values of the ellipsoidal reflector focal parameter $p_{1}=11 \mathrm{~mm}, p_{2}=16.875 \mathrm{~mm}$ and $p_{3}=22.75 \mathrm{~mm}$

Thus, the ER working window decrease allows concentrating the collected radiation on a plane with a smaller area, for example, with limited sizes of photodetectors, which are located in the ER second focal plane of biomedical photometers. By reducing the focal parameter, one should operate the BT optical properties and consider the ER efficiency in transmitted and reflected light (formula (5) and (6) respectively). Also, varying the probing laser beam profile [26] and diameter [28]. The ER ellipticity (4) and the inverse value - eccentricity (2) - are actually in assessing the imaging quality of the scattering spot, located in the reflector first focal plane, in the ER second focal plane. In this case, given the system axial symmetry, the quality assessment can be made by analyzing the ellipsoidal reflectors aberrational properties such as the Centroid [29] and RMS [30]. 


\section{Conclusion}

The optical properties of biological media (scattering and absorption coefficients, scattering anisotropy factor, refractive index) and the samples' geometric dimensions, particularly the thickness, are predetermined when choosing the ellipsoidal reflectors parameters for registration of the scattered light. The coordinates of the output of photons and their statistical weight, obtained in the Monte Carlo simulation of light propagation in biological tissue, have a physical effect on a characteristic scattering spot formation in the receiving plane of a biomedical photometer with ellipsoidal reflectors.

It is sufficient to use a predictive assessment of the values of ellipsoidal reflector efficiency indexes in transmitted and reflected light to investigate the samples of biological tissues with different relations between scattering and absorption coefficients in the visible spectrum. In a routine experiment with various samples in a wide range of variable thicknesses, it is advisable to supplement the rationale for the choice by analyzing the value of the ellipsoidal reflectors' efficiency factor.

The ellipsoidal reflector ellipticity has a slight effect on the illuminance of different zones of photometric images with a correctly selected focal parameter in the range of $0.6-0.8$. Therefore, in the absence of requirements for the aberration properties of ellipsoidal reflector ellipticity is chosen for their technological features of production and available equipment.

\section{References}

1. Tuchin V.V. Handbook of Optical Biomedical Diagnostics, In 2 vol., vol. 1. Bellingham. WA. USA, 2016, 864 p. DOI: $10.1117 / 3.2219603$

2. Meglinski I. Biophotonics for Medical Applications $1^{\text {st }}$ Edition. Woodhead Publishing, 2014, 402 p.

3. Bezuglyi M.A., Bezuglaya N.V. Ellipsoidal reflectors in biomedical diagnostic. Biophotonics, Riga, 2013, vol. 9032. DOI: $10.1117 / 12.2044606$

4. Bezuglyi M.A., Pavlovets N.V. Optical Biometry of Biological Tissues by Ellipsoidal Reflectors in Clinical and Biomedical Spectroscopy and Imaging III. Optical Society of America, 2013, vol. 8798, p. 87980Q.

DOI: $10.1117 / 12.2031142$

5. Bezuglyi M.A., Yarych A.V., Botvinovskii D.V. On the possibility of applying a mirror ellipsoid of revolution to determining optical properties of biological tissues.
Optics and Spectroscopy, 2012, vol. 113, no. 1, pp. 101107. DOI: $10.1134 / \mathrm{S} 0030400 X 12070053$

6. Morris P. Biomedical imaging: applications and advances. Woodhead publishing series in biomaterials. Cambridge. Waltham: Elsevier WP, 2014, no. 63, pp. 307-318.

7. Wang L., Jacques S.L. Optimized radial and angular positions in Monte Carlo modeling. Med. Phys., 1994, vol. 21(7), pp. 1081-1083.

8. Yaroslavskij I.V., Tuchin V.V. Optics and spectroscopy, 1992, no. 4(72), pp. 934-939 (in Russian).

9. Ivanov Yu.S., Monsar O.O., Synyavskyj I.I. Production of deep aspherics by trajectory copying and its application. Bulletin of NTUU "KPI". Instrument making, 2004, vol. 28, pp. 24-28 (in Ukrainian).

10. Lister T., Wright P.A., Chappell P.H. Optical properties of human skin. J. Biomed. Opt., 2012, no. 17(9), pp. 090901. DOI: 10.1117/1.JBO.17.9.090901

11. Symmons A., Lifshotz M. Field Guide to Infrared Optical Materials. SPIE PRESS: Bellingham Publ., Washington, 2021, $210 \mathrm{p}$.

12. Friz M., Waibel F. Coating materials. Optical Interference Coatings. Springer-Verlag Publ., 2003, pp. 105-130.

13. Okatov M.A., Antonov E.A., Bajgozhin A. Directory of optician-technologist. $2^{\text {nd }}$ ed. SPb: Politekhnika Publ., 2004, 679 p.

14. Zinchenko V.F., $\quad$ Antonovych V.P., $\quad$ Magunov I.R., Kocherba G.I., Sobol V.P., Mozkova O.V., Gorshtejn B.A. Film-forming materials and multilayer coatings of interference optics of technological IR lasers. Science and innovation, 2009, pp. 5-10 (in Ukrainian).

15. Putilin E.S. Optical coatings. Tutorial: SPbGUITMO Publ., 2005, 199 p.

16. Naba K.S., Sahoo N.K., Kumar S., Tokas R.B., Jen S., Thakur S., Reddy G.L.N. Postanalyses of an optical multilayer interference filter using numerical reverse synthesis and Rutherford backscattering spectrometry. Applied Optics, 2013, vol. 52, no. 10, pp. 2102-2115.

DOI: $10.1364 / \mathrm{AO} .52 .002102$

17. Field E.S., Bellum J.C., Kletecka D.E. Repair of a Mirror Coating on a Large Optic for High Laser-Damage Applications Using Ion Milling and over-Coating Methods. Laser-Induced Damage in Optical Materials, 2016, no. 56(1). DOI: 10.1117/1.OE.56.1.011002

18. Agcayazi T., Chatterjee K., Bozkurt A., Ghosh T.K. Flexible Interconnects for Electronic Textiles. Advanced Materials Technologies, 2018, no. 3(10), 32 p.

DOI: $10.1002 / \mathrm{admt} .201700277$

19. Wang L., Lihong W., Jacques S.L., Zheng L. CONV - convolution for responses to a finite diameter photon beam incident on multi-layered tissues. Computer methods and programs in biomedicine, 1997, vol. 54, pp. 141-150. 
20. Pawley J.B. Handbook of Biological Confocal Microscopy, $3^{\text {rd }}$ ed. By James B. Pawley, Editor. Springer Science \& Business Media: LLC, New York, 2006, $985 \mathrm{p}$.

21. Yaroslavsky A.N., Schulze P.C., Yaroslavsky I.V., Schober R., Ulrich F., Schwarzmaier H.J. Optical properties of selected native and coagulated human brain tissues in vitro in the visible and near infrared spectral range. Phys Med. Biol., 2002, vol. 47, no. 12, pp. 2059-2073. DOI: 10.1088/0031-9155/47/12/305

22. Caigang Z., Quan L. Review of Monte Carlo modeling of light transport in tissues. $J$. of Biomedical Optics, 2013, no. 18(5), pp. 050902-1-050902-12.

DOI: $10.1117 / 1$.JBO.18.5.050902

23. Bezuglyi M.A., Bezuglaya N.V., Helich I.V. Ray tracing in ellipsoidal reflectors for optical biometry of media. Appl Opt., 2017, no. 56(30), pp. 8520-8526.

DOI: $10.1364 / A O .56 .008520$

24. Xue L.L., Zhang C.P., Wang X.Y., Zhu M.-Yao, Zhang L.S., Chi R.H., Zhang J.D., Zhang G.Y. Monte Carlo simulation of light transport in five-layered skin tissue. Chin. Phys. Lett., 2000, vol. 17, no. 12, pp. 909-911. DOI: $10.1088 / 0256-307 X / 17 / 12 / 019$

25. Bezuglyi M., Bezuglaya N. Raman spectroscopy principles for in vivo diagnostic by ellipsoidal reflectors. Electrical, Control and Communication Engineering,
2019, vol. 15, no. 1, pp. 39-46.

DOI: 10.2478 /ecce-2019-0006

26. Bezuglyi M., Bezuglaya N., Kostuk S. Influence of laser beam profile on light scattering by human skin during photometry by ellipsoidal reflectors. Devices and Methods of Measurements, 2018, vol. 9, no. 1, pp. 56-65. DOI: $10.21122 / 2220-9506-2018-9-1-56-65$

27. Ritz J.-P., Roggan A., Isbert Ch., Mueller G., Buhr H.J., Germer Ch.-T. Optical Properties of Native and Coagulated Porcine Liver Tissue Between 400 and $2400 \mathrm{~nm}$. Lasers in Surgery and Medicine, 2001, vol. 29, no. 3, pp. 205-212. DOI: 10.1002/lsm.1134

28. Budagovskij A.V. Distant cell-to-cell communication. Monograph. M.: NPLC “Technique Publ.", 2004, $104 \mathrm{p}$.

29. Fuerschbach K., Jannick P.R., Thompson K.P. A new family of optical systems employing $\varphi$-polynomial surface. Opt. Express, 2011, vol. 19, iss. 22, pp. 21919 21928. DOI: 10.1364/OE.19.021919

30. López-Gil N., Fernández-Sánchez V., Legras R., Montés-Micó R., Lara F., Nguyen-Khoa J.-L. Accommodation-Related Changes in Monochromatic Aberrations of the Human Eye as a Function of Age. Investigative ophthalmology \& visual science, 2008, no. 49, pp. 1736-1743.

DOI: $10.1167 /$ iovs.06-0802 